\title{
ІСТОРІЯ СТАНОВЛЕННЯ ТА СУЧАСНИЙ СТАН СИСТЕМИ КАТОЛИЦЬКИХ МЕДІЙ УКРАЇНИ
}

\author{
Наталія Гадьо \\ Львівський національний університет імені Івана Франка, \\ вул. Генерала Чупринки, 49, 79044, Львів, Україна \\ e-mail: nataliagado@yahoo.com
}

Схарактеризовано передумови та етапи становлення системи католицьких медій двох обрядів в Україні. Закцентовано на тому, що сучасна медіасистема католицьких засобів соціальної комунікації в Україні складається з ресурсів двох обрядів - римо-католицьких та греко-католицьких. Через аналіз засобів соціальної комунікації виявлено, що сьогодні її становлять відновлені після здобуття Україною незалежності видання та нові, тісно пов’язані з католицькими видавництвами, присутні в інтернеті. Визначено, що католицька медійна система України свідчить про наближеність до медійних систем Ватикану, Польщі та Італії, особливо спільним контентом і тенденцією до конвергенції медій у значенні зближення і взаємовпливу.

Ключові слова: католицька медіасистема в Україні, засоби соціальної комунікації (3СК), католицькі медії, католицьке телебачення, католицьке радіо, католицькі видавництва, друковані видання.

В Україні розвиток релігійних ЗСК (засобів соціальної комунікації) розпочався після прийняття в квітні 1991 року Закону України «Про свободу совісті та релігійні організації», ст. 22 якого надала юридичне право релігійним організаціям «...виготовляти, експортувати, імпортувати і розповсюджувати предмети релігійного призначення, релігійну літературу та інші інформаційні матеріали релігійного змісту» [1].

Сучасна система релігійних медій в Україні сформувалася впродовж 1991-2009 pp. Одною з її складових є католицькі засоби соціальної комунікації (далі - ЗСК), власну складну систему яких складають медії двох обрядів - римо-католицькі та греко-католицькі. Оскільки розгалужена мережа католицької преси, створена на початку XX ст., була повністю зруйнована після ліквідації УГКЦ 1946 р. та за часів комуністичної цензури, то сучасну систему католицьких ЗСК довелось створювати заново після здобуття незалежності України. На початку 1990-х рр. відновлюють свою діяльність ті католицькі видання, які вимушено перестали функціонувати наприкінці 30-х рр. минулого сторіччя, з появою інтернету з'являються їхні мережеві версії. А згодом - власне інтернет-видання та інші сайти Католицької Церкви обох обрядів. Станом на 2010 р. РКЦ в Україні мала 13 періодичних видань (шість у 1995 р.), з яких майже усі мали мережеві версії або їх можна було переглянути у пдф-форматі. Не-

(C) Гадьо Н., 2018 
зважаючи на невелику кількість видань, вони охоплювали весь тематичний спектр. Це були: наукові («Колегія»), сімейні («Проповідник») молодіжні («Мир вам»), дитячі («Зернятко Слова») періодичні видання. Станом на 2016 р. продовжують виходити лише деякі з них, що мають підтримку офіційних структур РКЦ.

Дуже часто періодика виходила у редакціях католицьких видавництв та монаших згромаджень, як це бачимо в медійній системі Польщі та Італії. Наприклад, видавництво РКЦ «Кайрос», засноване 1993 р. в Інституті релігійних наук св. Томи Аквінського в м. Києві, донедавна видавало журнали «Колегія», «Католицький вісник», журнал «Проповідник» та щомісячний «Бюлетень релігійної інформації».

Провінція Святого Архангела Михаїла Ордену Менших Братів (францисканців) в Україні видає «Католицький Вісник» (до 2008 р. «Парафіяльна Газета»): всеукраїнський двотижневик пропонує новини з Ватикану та світу, огляди й статті про події в Церкві на українській землі, коментарі до недільних читань, пояснення Літургії, роздуми над Святим Письмом, статті молодіжного, соціального, історичного, культурного спрямування.

Деякі з часописів, які зафіксовані у дослідженнях до 2010 р., зараз не виходять друком (наприклад, «Аве Марія»). Продовжують виходити - журнал Отців Маріанів «Слово між нами» (1998) за взірцем американського журналу «The Word Among Us». Від 2013 р. починає виходити науковий щорічник Теологічного інституту ім. Йозефа Більчевського «Studia Leopoliensia».

Релігійно-суспільне видання Луцької дієцезії РКЦ в Україні «Волання з Волині» (Wolaniecom.parafia.info.pl), засноване 1994 року, видає римо-католицька парафія м. Острог, Рівненської обл. Кольорова парафіяльна газета «Przygotujcie drogę Panu» парафії Усікновення голови Івана Хрестителя, м. Самбір виходить від 2006 р. - можна розміщений на сайті парафіï samborparafia.at.ua. Дитячий журнал «Водограй» (почав виходити 2001 р. як експериментальне видання під назвою «Твій журнал» 3 ініціативи о. Веслава Степненя і благословення єпископа Станіслава Широкорадюка), від 2006 року має сторінку в інтернеті (Vodograj.org.ua) з інтерактивними іграми, розмальовками та конкурсами, а з 2008 р. - російськомовну щомісячну версію 3 передплатою на пострадянській території. У 2001 р. журнал стартував з накладом 800 примірників, а сьогодні виходить близько 14 тис. Кожен номер видання має тему, відповідно до підручника МОН України для спеціалізованого курсу з християнської етики. Дитячий журнал має і дорослі рубрики: «Роздуми над Євангелієм», «Будьмо ввічливі», «Сторінка для батьків». «Водограй» безкоштовно надсилають до сиротинців та інтернатів. 3 нагоди 100 випуску журналу у 2011 р. редакція почала видавати журнал «Водограйчик» для найменших читачів віком 3-7 років. Система римо-католицьких медій України подібна до польської: вона складається з відновлених після здобуття Україною незалежності видавництв та періодики, а частково - зі створених в умовах інтернетизації ЗСК. Однак подібність бачимо не тільки історичну, а й за хронологією творення та розвитку.

Сучасні друковані видання виходять паралельно до роботи однойменного інтернет-ресурсу, який є контентотворчим, а не навпаки, як це було в 1990-pр. До прикладу, загальноукраїнський католицький суспільно-релігійний часопис «CREDO» висвітлює питання віри в сучасному світі, був заснований в 1992 році. Від 2002 року випуск «CREDO» було призупинено. I лише від 2006 року канцлер Кам'янець-Подільської дієцезії о. Віталій Воскобойнік відновив вихід часопису на рівні Кам'я- 
нець-Подільської дієцезії. Видання має наклад 1999 примірників. Його розповсюджують у католицьких парафіях України. А від 2009 р. має також сайт (Credo-ua.org).

Найчастіше видавцями римо-католицької періодики в Україні $є$ церковні адміністративні одиниці - єпархії, парафії. Види церковної періодики РКЦ є тотожними з періодикою УГКЦ. Однак кількісно УГКЦ має більше видавництв і періодики. Станом на 2010 р. їх було 27 (12 у 1995 р.) [3]. УГКЦ також є чисельнішою, аніж РКЦ. Ïї громади становлять 10,7\% від загальної кількості релігійних громад в Україні, а громади РКЦ $-2,7 \%$.

Систему друкованих медій УГКЦ сьогодні становлять відновлені та нові видання, які тісно пов'язані з видавництвами і на різних етапах становлення і розвитку починають бути присутніми в інтернеті. Один із найстаріших в Україні релігійних журналів «Місіонар» з'явився 1897 р. у видавництві Чину св. Василія Великого (ЧСВВ). Отці-василіяни від 1895 року друкували богослужбову, катехитичну, літургічну літературу, прозові та поетичні твори релігійного змісту, дитячі духовні книги, науково-історичне видання «Записки ЧСВВ» та католицький часопис «Miciонар», довоєнний тираж якого доходив, як фіксує Ю. Щербяк, до 50 тис. екземплярів [5, с. 91], і «Малий Місіонарчик». Після 1939 року видавнича діяльність ЧСВВ була перервана на чотири десятиліття. Лише наприкінці 1980-х - на початку 1990-х років отці-василіяни відновили роботу видавництва в Україні. У квітні 1992 року з'явилося перше число відновленого «Місіонаря». Як фіксує М. Лозинський, до створення перших чисел також були задіяні наукові працівники факультету журналістики Львівського університету імені Івана Франка - Й. Лось, М. Лозинський, М. Присяжний та О. Федик. Тематику випусків становили богословські, морально-етичні та суспільно-важливі статті [2, с. 263]. 3 нагоди 115-річчя журналу «Місіонер» від 2012 р. до 2016 р. він виходив також в електронній версії - Misionar.info. Інформативне наповнення сайту, окрім матеріалів друкованого видання, приблизно на $70 \%$ становив контент інших інтернет-ресурсів. А в архіві сайту можна було знайти оцифровані примірники журналу ще від $1897 \mathrm{p}$.

Ще одним видавництвом УГКЦ є «Свічадо», засноване студентами польського Католицького університету м. Любліна (1987), а 1992 р. - перенесене до Львова, де діс як видавничий відділ Монастиря монахів Студитського уставу. Окрім християнських книг, які можна замовити в інтернет-магазині видавництва, виходять: дитячий християнський журнал «Зернятко» (2001), молодіжний журнал «Сто талантів» (2005), християнський журнал для всієї родини - «Кана» (2012).

Одним 3 наймолодших є видавництво «Апостол» (2016). Свою місію видавництво бачить у друці книг, журналів та інших ЗСК для поширення справи євангелізації та католицької апологетичної думки. Від 2011 р. видає журнал «Слово» - християнський євангелізаційно-апологетичний журнал, присвячений сучасній католицькій думці. Кожен номер «Слова» присвячений певній темі та містить постійні рубрики, як-от: «Словотерапія», де християнський психолог ділиться з читачами способами розв'язання проблем; «Рецепти святості» - про життя і таємниці святості святих Католицької Церкви; «Місія» - роздуми над місією в житті Церкви окремих рухів чи конкретних людей; «Роздуми над Словом»- недільні літургійні читання 3 короткими розважаннями та коментарями. «Апостол» має свій мультимедійний сайт (Apostol.if.ua), де, окрім інтернет-крамниці, розміщена продукція телестудії. 
Також католицьку літературу видають (дата заснування у дужках): «Стрім» (початок 1990-х), «Нова Зоря» м. Івано-Франківська (1995), видавництво парафії Різдва Пресвятої Богородиці «Храм», м. Львів (1995), видавництво УКУ (2003), видавництво спільноти св. Миколая «Вогонь з неба» (2006), «Бібліотека «ВХЦ» (2014) та ін.

Як бачимо, періодика УГКЦ також тісно пов'язана з видавництвами, як і видання РКЦ. Однак буває і навпаки: редакція часопису ініціює створення видавництва. Прикладом є видавництво «Нова Зоря», створене на базі однойменної газети.

Як фіксує І. Швець, перед Другою світовою війною в Україні існували багатотиражні україномовні газети [4, с. 415], не всі з яких відновили своє існування після падіння комунізму. Також чимало нових видань, які дослідники вважали прикладами якісної преси, наприклад, газета «Арка», припинили своє існування. Однак кількість друкованих видань за останні роки не зменшується, незважаючи на активну інтернетизацію, через появу нових. Від початку 2015 р. виходять: «Живе слово», «Домашня Церква», «Жива вода», «3 любов’ю в світ».

Окрім видавництв та періодики, до структури медій Католицької Церкви в Україні належать радіо- та телестудії. Католицьке радіомовлення та телебачення в Україні сьогодні транслюється зазвичай через супутниковий та інтернет-зв'язок. За невеликими винятками, католицькі програми не транслюють ані державні, ані комерційні канали. Визначаємо три типи радіостанцій, присутніх в інтернеті: ті, що ведуть мовлення і традиційно, і через інтернет (аналоговим чи цифровим способом); інтернет-радіо (тільки в інтернеті); радіостанції-архіви. Сьогодні діяльність ведуть католицькі радіостанції усіх трьох типів.

Понад двадцять років в інформаційному просторі України виходило в ефір радіо «Воскресіння» (1992), яке мало свою інтернет-версію (rr.lviv.ua). Сьогодні це приклад інтернет-архіву, де також знаходимо архів бюлетеня «Агенції релігійної інформації» та газети «Мета». У 2015 р. радіо зупинило свою роботу на час реорганізації і почало виходити у новому форматі - як цілодобова інтернет-радіостанція. Відтак трансформувалося у перше і єдине в Україні католицьке інтернет-радіо (reradio.com. ua).

Прикладів радіо, що ведуть мовлення і традиційно, і в інтернеті є кілька. Це найперше радіо «Світанок», яке розпочало свою роботу 2002 року 3 трансляцій Божественних Літургій $з$ коментарем, спільних молитов і роздумів над Святим Письмом. Радіоефір доповнили тематичні розділи «Роздуми над важливим», «Сходинками Церкви», «Лірична сторінка», «Світ дитячої Біблії», «Новини», «Світло надії». Організатори заснували телефон довіри, до 2011 р. випускали газету «Живе Слово». 32012 року радіо «Світанок» має свій сайт radiosvitanok.org.ua, де можна знайти програму передач, окремі програми і подкасти.

«Радіо Марія» в Україні почало мовлення 1 червня 2010 року в м. Києві, а зараз розширило мовлення на інші обласні центри. В ефірі радіо спочатку звучала лише музика, згодом з'явилися програми, найперше, - молитовні трансляції. Зараз «Радіо Марія» має 24 години мовлення; денні програми ведуть майже виключно у прямому ефірі. Щоденна аудиторія «Радіо Марія» - близько 50 тис. осіб. Усі програми можна поділити на три формати: молитовні програми (Літургія годин, Розарій, св. Літургія), катехези* та вчення Церкви, програми соціального спрямування. «Радіо Марія»

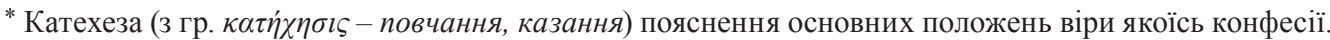


$\epsilon$ всесвітньою мережею католицьких радіостанцій, які ведуть мовлення в понад 70 країнах світу, а також в інтернеті.

Найстаршою католицькою радіостанцією в українському ефірі та від 1999 року в інтернеті $€$ «Радіо Ватикану» (Radiovaticana.org). Українська онлайн-версія діє від 2006 року. Вона, як й інші веб-сторінки різними мовами, містить інформацію про діяльність Папи (Аудієнції, «Ангел Господній», Апостольські подорожі), найважливіші новини Католицької Церкви та світу, можливість радіо- та аудіопрослуховування і перегляду відеоновин у записі.

РКЦ в Україні має свій медіа-центр в інтернеті (Католицький медіа-центр Kmc.in.ua), в якому інформація подається українською, російською, польською, англійською, іспанською та іншими мовами.

В Україні від 2011 р. працює телестудія першого католицького телебачення «EWTN - Телебачення Віковічного Слова» (РКЦ, Київ), що є філією американської редакції, яка транслює програми через телебачення та інтернет. Український сайт телебачення поєднує трансляцію наживо англійською і українською мовами, архів програм, текстові новини, анонси, опитування, перехід у соцмережі, інтернет-магазин католицької літератури, відео і анімації, сайти партнерів. Його контент складають релігійно-освітні програми, серед яких особливо варто відзначити програми для молоді та дітей («Чисте життя», «Твоє покликання», «Добрий монах», мультиплікаційні «Моя християнська родина», «Ми - католики»). Програми дають відповідь, як жити вірою в сучасній культурі («Віра і Культура»), обстоювати свою віру («Причини вірити»).

Телестудія «Апостол» (м. Івано-Франківськ, УГКЦ) від 2008 року випускає програми «Знаки часу», «Днесь», «Жива віра», тематичні фільми про життя Церкви, а у планах має програми для подружжя, молоді та дітей. Під час подій на Майдані телестудія проводила Молитовний майдан наживо в онлайн-трансляції. Програми телестудії пояснюють розуміння Церквою суспільно важливих питань («ЗМІ», «Освіта і Церква», «Здоровий розум у здоровому тілі», «Мода і вбрання», «Волонтерство», «Церква для молоді», «Лідерство», «Патріотизм») і торкаються питань віри, моралі («Віра у Христове Воскресіння», «Милосердя», «Небайдужість», «Любов», «Методи планування сім’і»)). Випуски телепередач транслюють на місцевому телебаченні та розміщують на каналі в «YouTube».

Структурно подібною є програма «Скеля» (2010, м. Львів, РКЦ), творці якої прагнуть показати Церкву у зрізі минулого і сучасного через тематичні передачі та інформувати глядача про найважливіші новини з життя Католицької Церкви. Ї̈̈ контент поєднує інформацію глобального і локального масштабів.

Від 2012 року в інтернеті працюють два медіаресурси УГКЦ, архіви фото, відео- та аудіо файлів з найважливіших офіційних церковних та суспільних подій, семінарів, реколекцій: «Медіаресурс Української Греко-Католицької Церкви», який підтримує Департамент інформації УГКЦ (м. Київ), і «Католицький Медіаоглядач. Медіасайт порталу МСІ», який підтримує група католиків з благословення єрархії УГКЦ (м. Львів).

«Живе.ТБ» (УГКЦ) - перше в Україні католицьке соціально-релігійне інтернет-телебачення веде мовлення від 9 серпня 2013 року. Щоденний ефір в інтернеті «Живого.ТБ» складається з інформації про життя Церкви («Живі новини», «Наші люди», «Церковний рік») та про соціально значущі проблеми України («Відкрита 
розмова», «Відкрита студія», «Публічні люди»), які можна переглянути наживо на caйтi Zhyve.tv i на сторінці в соціальній мережі Фейсбук, на каналі в Ютубі. Назви програм підтверджують, що головною концепцією програм є відкритість УГКЦ до вірних та світу.

Інтерактивна програма «Відкрита Церква» у кожному випуску висвітлює важливу для суспільства тему 3 допомогою Блаженнішого Святослава, транслюється також на «5 каналі». Найновіший проект «Живого.ТБ» - «Відкрита Церква. Діалоги» пропонує глядачам не лише тематичну диференціацію кожної програми, а й окремого гостя - єпископа чи священика, який цю тематику висвітлює у жанрі телеінтерв'ю, відповідаючи на запитання ведучого і глядачів. Програма також розширює географічну карту запрошених гостей поза межі Києва, оскільки транслюється з львівської студії. Однак через можливості інтернету, технічної різниці між програмами немає.

Абсолютно новим підходом до українського телемовлення в інтернеті вважаємо програми сайту «Католицький Оглядач», які схожі до католицького інтернет-телебачення Італії та Польщі, де такі способи подачі інформації є традиційними. Формат відеошколи мають програми «Біблійна студія» та «Апологетика» о. д.-ра Романа Лаби, у якій автор проводить послідовні відеолекції з біблістики, пояснюючи доступною мовою складні історичні події та теологічні поняття. Розважально-пізнавальна програма «Суботня кухня з о. Віталієм», окрім кулінарних рецептів, подає католицьке розуміння свят та побутових звичаїв, наприклад, правил посту, святкування неділі, Різдва, Великодня. Жанр авторської католицької програми представляє цикл «Кава 3 цинамоном». Кожен випуск є розмовою двох священиків - о. ОрестаДмитра Вільчинського та о. Віталія Барабаша на важливу для глядача тему з життя Католицької Церкви локального чи світового масштабу. Наприклад, «Навіщо читати Біблію», «Символіка різдвяних звичаїв», «Що таке паломництво» та ін. За концепцією, програма відновлює традицію недільного спілкування галицьких священиків «за кавою» на духовно-суспільні теми. У найновішій програмі під робочою назвою «Стежками нашої спадщини» беруть участь історики, археологи, антропологи та ін.

Відеоконтент для дітей містить сайт мультимедійної студії «ClaraStudio» (РКЦ, м. Вінниця, під патронатом Ордену Братів Менших Капуцинів), яка віднедавна робить доступними в інтернеті безпечні дитячі телепрограми і мультфільми. Це пізнавально-освітні програми («Сателіт» - розповіді про все у світі, «Містечко Надія» повчальні пригоди дітей; «Кіт-мандрівник» - подорожі цікавими місцями України; «Добрі манери» - уроки етикету для дітлахів, «Професор» - програма, яка змушує відірватися від компютера, щоб самим повторити експерименти) і мультфільми на біблійні теми. Також на відеохостингу Ютуб доступні відеозаписи реколекцій, прощ, літургій, проповідей. Цікавим в цьому контексті є сайт Propovidnyk.com.ua, що містить відеозвернення отців-домініканів, кожне з яких можна тематично ідентифікувати за проблемою, розглянутою в ньому. Деякі сайти парафій регулярно проводять відеозйомку найважливіших подій, яку розміщують на відеохостингу і сайті парафії.

Для католицької комунікації дуже важливі нові технології й засоби зв’язку, які уможливлюють широкий доступ до вчення Католицької Церкви. Тепер це відображається на появі та вдосконаленні католицьких медій в інтернеті. Однак католицька медіасистема складається і з нових, і з «старих» ЗСК, що вважаємо послідовним продовженням медіастратегій Католицької Церкви. 


\section{СПИСОК ВИКОРИСТАНОЇ ЛІТЕРАТУРИ}

1. Закон України «Про свободу совісті та релігійні організації» (Відомості Верховної Ради УРСР (ВВР), 1991, №25, ст.283) [Електронний ресурс]. - Режим доступу до джерела: http://zakon0.rada.gov.ua/laws/show/987-12

2. Лозинський М. Часопис «Місіонар» - друкований апостол українського народу (1897-1944) / М. В. Лозинський // Вісник Львівського ун-ту. Серія журналістика. 2004. - Вип. 25. - С. 330-333.

3. Церковно-релігійна ситуація і державно-конфесійні відносини в Україні: підсумки десятиліття, тенденції і проблеми (аналітична доповідь Центру Разумкова), «Національна безпека і оборона», 2011, № 1-2 (119-120), с. 3-36 [Електронний ресурс] / Режим доступу до джерела: http://www.razumkov.org.ua/ukr/files/category_ journal/NSD119_ukr_1.pdf

4. Швець I. М. Відродження релігійної преси в Україні (1991-2011рр.) / Ірина Миколаївна Швець // Сучасні проблеми діяльності бібліотеки в умовах інформаційного суспільства: матеріали четвертої міжнародної науково-практичної конференції, 25 жовтня 2012 року. Львів: Видавництво Львівської політехніки, 2012. - С. 411421.

5. Щербяк Ю. А. Роль католицької періодики у просвітительській діяльності Української греко-католицької церкви в першій третині XX ст. / Ю. А. Щербяк // Збірник наукових праць Полтавського державного педагогічного університету імені В. Г. Короленка. Серія «Педагогічні науки». - Полтава. - 2012. - Випуск 54. C. 87-94. 


\title{
HISTORY OF DEVELOPMENT AND THE MODERN STATE OF THE SYSTEM OF CATHOLIC MEDIA OF UKRAINE
}

\author{
Nataliya Hado \\ Ivan Franko National University of Lviv, \\ Generala Chuprynky Str., 49, 79044, Lviv, Ukraine \\ e-mail:natalia_gado@yahoo.com
}

The development of religious means of social communication in Ukraine began after the adoption of the Law of Ukraine "On Freedom of Conscience and Religious Organizations" in April 1991 which provided legal authority to religious organizations.

An extensive network of Catholic press created at the beginning the 20th century was completely destroyed after the abolition of the UGCC in 1946 and during the communist censorship, the modern system of Catholic means of social communication had to be. At the beginning of the 1990s, those Catholic editions, which had ceased to function in the late 1930's, reestablished their activities, with the advent of the Internet, their network versions appear. And then - own Internet sites and other sites of both the Catholic Church rites.

Than the modern system of religious media in Ukraine has recreated after the declaration of independence of Ukraine and evolved 1991-2009.

Catholic media system has a hierarchical structure, where the first of them are the official media of the Apostolic Capital and the Churches of two rites. It is proved that the main media strategies are not identical in the matrix of media systems of Italy, Poland and Ukraine, but the Vatican's media, regardless of the level of development of Catholic media in individual countries, remain the basis for all Catholic communication. It is determined that the Ukrainian Catholic media system shows the proximity to the media systems of the Vatican, Poland and Italy, especially the common content and the tendency for convergence of media in the sense of convergence and mutual influence. However, it is in a state of formation and implementation of the concepts of Internet resources using technologies Web 2.0. Convergent signs and the level of technology use Web 2.0 are emerging as a realization of the strategy for improving media.

New technologies and communication tools are very important for Catholic communication, which allow broad access to the teaching of the Catholic Church. Now this is reflected in the emergence and improvement of Catholic media on the Internet. This is considered a continuation of the media strategies of the Catholic Church.

Key words: the Catholic media system in Ukraine, the means of social communication, Catholic media, Catholic television, Catholic radio, Catholic publishing houses, press. 